\title{
Research on the present situation and development strategy of universities
}

\author{
Xiao-Xian Lv ${ }^{1}$ \\ ${ }^{1}$ Academic Affairs Division, \\ China University Of Geosciences Great Wall College, \\ Baoding, China
}

\begin{abstract}
In the 21st century, relying on technological innovation to enhance the comprehensive national strength and core competitiveness of the country, establishment of a national innovation system has become the common choice of governments. 18th CPC National Congress proposed the implementation of "innovation-driven development strategy," with Chinese characteristics and strive to create innovative entrepreneurial talent development system. Colleges and universities is to cultivate talent base, shoulder the conveying talents for socialist modernization. The success of national strategic target transformation, largely depends on the training of talents, it seems that transformation of colleges and universities is imminent. At present,in the practice of the development of colleges and universities transformation, suffered a "why turn" "turn what" and "how to turn"confusion and conflict. Sort out the present situation, the nature of the transformation of colleges and universities and the path has become a reality in front of college transformation development and pressing problems, directly related to the direction of the transformation of the local undergraduate universities, efficiency, and the success or failure.
\end{abstract}

This paper describes the background, current situation analysis and transformation of the nature of Universities transformation, ultimately providing policy analysis for the transformation goals for universities.

Key words- university,transformation,current situation, analysis

\author{
Lan Yang ${ }^{2}$ \\ ${ }^{2}$ Management Science and Engineering School, \\ China University Of Geosciences Great Wall College, \\ Baoding, China
}

\section{INTRODUCTION}

Since the 1990s, it is an important period for China's development and reform of higher education. With China's economic and social development, the transformation of economic system and the progress of science and technology, higher education as the first talent resources has become more and more important. To adapt itself to the changing economic system after reform and opening up, in order to adapt to the needs of the sustained and rapid economic and social development of talent, we must carry on the transformation of colleges and universities

The change of the political, economic, cultural and social environment inevitably leads to the change of the university,.To some extent, the University has been constantly engaged in transition, but under different circumstances will be different forms. At present, promote the transformation of development no doubt has become a key issue of higher education reform, social concern hot issues and difficult problems in self development of colleges and universities.

(1) The change of national policy requires a corresponding change education pattern in colleges and universities

China is in a crucial period of deepening reform, economic construction, political construction, cultural construction, social construction and ecological civilization is building, Industrialization, informationization, urbanization, marketization and internationalization in-depth development, population, 
resources and environment pressure increasing, These are all highlights the importance and urgency of training innovative talents. The change of the policy is bound to lead to the change of development mode in colleges and universities.

(2) Popularization of higher education brings the change of environment and development in colleges and universities

Popularization of higher education is the main trend of the 20th century, especially after the $70 \mathrm{~s}$, the world within the scope of the popularization of higher education is developing rapidly. Take China as an example, in 2010 the number of colleges and universities is 2358 , and by July 9, 2014, a total of 2542 universities throughout the country. Universities in just four years has increased by 184 , an increase of 8 percent, equivalent to an increase every year in 46 . An increase in the number of school, makes the competition of various educational resources among institutions of higher learning. To adapt to the trend of the times change, and enhance the competitiveness of all aspects of the school, universities transformation is imminent.

(3) Demand for innovative and practical talents make universities must change their patterns of education.

To build an innovative country must have a strong and innovative scientific and technological personnel for support. And training innovative talents of science and technology is a systematic project, which requires colleges and universities to cultivate a large number of talents in this field.As usual, Universities have been focusing on all-round general theoretical knowledge,which has a real different with the practice. Along with the demand for practical talents, the university would have to train a large number of practical talents and they also need to change the the education idea.

\section{Development Status}

In the face of the current round of the transformation of government-led top-down development, colleges and universities showed a different attitude and action.It can be summarized as five types:

(1) Conservative. This kind of university education has been in a closed state, conformism, has blind confidence about their teaching way. They are indifferent to social and economic changes and the development of higher education, and even do not want to change everything.

(2) Traditional.This kind of universities adhere to the"only academic theory"value orientation, equate academic equivalent to high level but applied to low level and simply copy the research-oriented universities academic oriented operation mode. Influenced by traditional ideas, they are worried that once the teaching profession in the direction of change will reduce the level of school.

(3) The practical. This kind of colleges and universities think: transformation development is just a way and means of school development, the transformation is not an end, the real purpose is to enhance the status and social influence of the school, obtain school dividend policy development needs.

(4) Blind type. This kind of colleges and universities only listen to the views of the government, completely regardless of the trend of the development of the education and the growth of the students needs. As long as the government claims,they will stick to it. This obedient attitude is certainly good, but the results are often unsatisfactory.

(5) Loss type.Although these universities realise the necessity of transformation to practice, establish the transformation development strategy, but lack of method on specific actions. They do not know how to start. This reflects the lack of experience on the education transition.

Throughout the above five types, although the performance is different, they imply a few common problems: applied understanding fuzzy, applied education lack of experience or applied managerial ability is insufficient. Many universities don't even know why they need the transformation and the degree of the transformation. Therefore, the primary problem of 
transformation in colleges and universities is: to make clear of the essence of the transformation of development.

\section{The connotation of the transformation and development}

In the "modern Chinese dictionary",there are two interpretation of "transformation"The first one means: socio-economic structures, cultural patterns and values shift; the other one means: conversion product model or structure. On this basis, we believe that the transformation is a kind of pain, is not naturally produced but conscious. It has the characteristics of the direction of the indicative.

In a sense, the transformation in the development of the universities is the awakening of the crisis on its own development. The transformation of the development of colleges and universities is based on the reality of a face-to-face environment,.This is a kind of all aspects of adjustment and change of self-awareness and a necessity of historical development. Its essence is scientific regression and implementation of the College's mission connotation development.

\section{Basic Strategy}

With the transformation of national policy, a surge of demand for applied, entrepreneurial talent. It is necessary to make corresponding change for universities.

(1) A clear transition categories and development positioning is the precondition of transformation development.

The school-running orientation is the direction of a school, command the overall situation of school work, and guide the reform and development direction of the school. School development can not be the same, not homogenization.Every universiy must take its own road running to lead the development characteristics, understanding the process of restructuring and development, they must first recognize their own stations. Due to the history and the professional category is different, to the design of the talent training scheme will also be different. The orientation of the development of universities mainly includes the school type, orientation of talent training, service oriented, etc.Universities should deeply grasp its own historical background and social roots, identify their mission, and establish "bachelor, teaching and application, the local" four basis points, firmly set up the consciousness of service for the local economic and social development, strengthen the interaction with regional economic and social, insist on do this direction adapted to themselves.

\section{(2) Transformation of education idea}

University idea is the precondition for the university of connotation construction.It is also the thought,spirit and soul for the university.It is not only decide the university today,but also influence the university tomorrow. How should an university development is not entirely determined by both the traditional schools, and is not determined by personal will, but by the degree of social demands on the schools. Universities must update their concepts, enhance the concepts, under the guidance of new teaching methods to adapt to new educational requirements.

(3) The teachers troop transformation

To cultivate professional talents must have the corresponding teachers, these teachers should not only have certain professional knowledge, but also have some practical experience. Currently, there is a general problem in universities: too much emphasis on academic and theoretical, while ignoring the ability and practice, ignoring the ability-transform the theory into technology and productive. To grow up in a short time for teachers who have the dual qualities is a painful thing, but also a difficult thing,and this is also a difficult point for the transformation of university development.

Universities in transition development, on one hand to strengthen the training of in-service teachers, as far as possible to arrange professional teachers to field practice, lead teachers for the enterprise to carry out technical services, to accumulate practical experience, enhance practical teaching ability.On the other hand,universities can hire some senior management from enterprises or 
other schools to teach and strive to improve the overall standard of university teachers.

(4) Adhere to the student as the core concept

In the process of transformation of universities, it is really important to focus on the students' real demands. This requires these schools to further deepen the educational reform, from a "teacher-centered" to "student-centered" change, from the classroom teaching to practice teaching, give full play to the students in the process of practical teaching evaluation, and train students to become social needs practical talents.

In training students' application ability at the same time, pay attention to strengthen students' innovation spirit, innovation consciousness, innovation ability and social sense of responsibility is also very important.

(5) Strengthen the construction of specialization

In the transformation of development, the universities should reflect economic and social development in the service area of educational philosophy, the school discipline specialties should be closely integrated with the local economic and social development.

First, universities should make promote local economic development as the goal, adjust and optimize the structure of academic disciplines, including setting up new industries need to adapt to the local specialty, the abolition of the development lags behind. Focus on the economic benefits associated with the local run of professional and build both local characteristics and practical value of the professional.

Second, universities should in accordance with the requirements of the professional disciplines of docking industry and the industrial chain, integration of school education resources, promote the intersection of disciplines, building characteristics and advantages of professional disciplines cluster.

(6) The trinity and collaborative development

Restructuring and development is not only the school's own things, but also the common responsibility of the government, society, universities. In the development of the whole transformation of colleges and universities, universities, enterprises and research institutes should play different roles. Generally speaking, colleges and universities in the development of transformation, should pay attention to "the trinity" and collaborative innovation. Under the government guidance, improve scientific research ability, service level and quality of personnel training.

First of all, the government should play leading role. In major policy, talent supply and demand of monitoring, professional qualification, employment access, education quality evaluation, etc., the government must play an important role. To changing the function of local education administrative departments, and make it become a bridge of cooperation between school and industry enterprises.

Second, strengthen the industry enterprise responsibility. Universities and enterprises should take the initiative exchange, exchanges,and ultimately achieve a win-win.

Third, universities should fully listen to the views of employers and industry experts, revise the training program, and make prepare for talents training.

\section{Conclusion}

With the change of national policies and market demand, restructuring and development of colleges and universities is a historical necessity: it is necessary to strengthen the teaching of theoretical knowledge, but also to develop students' professional skills. However, the restructuring and development of universities is not simply turn direction, the key is to turn the path and focus on quality, adhere to the connotation type development. Both in transition, but also to reform; it is necessary to adhere to honesty, but also innovation. As long as "respect for history, the reality of care, for the future," as long as "follow the law, bearing in mind the mission, the connotation of development," as long as "based on local, application oriented, open schools", universities must be able to transform successfully. 


\section{Acknowledgements}

This research is supported by Research and Practice of Teaching Reform of High Education in Hebei Province :Research on Transitional Development Strategies of Independent Colleges(No.SZ16132)

\section{References}

[1] Shengjun Wang.Study on the Path of Transformation of Civilian-run Colleges and Universities From the Perspective of Enrepreneurial University.[M]. Tianjin University Press,2013.5.

[2] Beisheng Wang,Mingcheng Xu.Analysis of
Strategies for the Transformation of Local Universities.[J].Journal of Zhengzhou Normal Education ,2015,5 (4).

[3] Linsheng Zhu.On the Status,Connotation and Strategy of the Transformation Development of Local Undergraduate Universities.[J].Journal of Huaiyin Teacheers College,2015,4（37）.

[4] Junfeng Yan.Research on the Development Strategy of Industry Characteristics Universities.[D]. China University of Mining and Technology,2014,6. 